\title{
CAN Foreign LobBying EnHance DeVElopMent? THE CASE OF TOURISM IN THE CARIBBEAN
}

\author{
KISHORE GAWANDE ${ }^{1}$ \\ TEXAS A\&M UNIVERSITY \\ WiLliam MaLONey \\ WORLD BANK \\ Gabriel V. MONTES RoJas \\ UNIVERSITY OF ILLINOIS, URBANA-CHAMPAIGN
}

\begin{abstract}
There exist legal channels for informational lobbying of U.S. policymakers by foreign principals. Foreign governments and private sector principals frequently and intensively use this institutional channel to lobby on trade and tourism issues. This paper empirically studies whether such lobbying effectively achieves its goal of trade promotion in the context of Caribbean tourism and it is the first paper to examine the potential for using foreign lobbying as a vehicle for development. Panel data are used to explore and quantify the association between foreign lobbying by Caribbean principals and U.S. tourist arrivals to Caribbean destinations. A variety of sensitivity analyses support the finding of a strong association. The policy implications are obvious and potentially important for developing countries.
\end{abstract}

Keywords: Foreign Lobbying; Tourism; Panel data. Fixed Effects.

JEL Code: F13, O54, C2, C3.

World Bank Policy Research Working Paper 4275, July 2007

The Policy Research Working Paper Series disseminates the findings of work in progress to encourage the exchange of ideas about development issues. An objective of the series is to get the findings out quickly, even if the presentations are less than fully polished. The papers carry the names of the authors and should be cited accordingly. The findings, interpretations, and conclusions expressed in this paper are entirely those of the authors. They do not necessarily represent the view of the World Bank, its Executive Directors, or the countries they represent. Policy Research Working Papers are available online at http://econ.worldbank.org.

\footnotetext{
${ }^{1}$ Corresponding author. Bush School of Government and Department of Economics, Texas A\&M University. Phone: (979) 458-8034. Email: kgawande@tamu.edu.

Funding from the World Bank is acknowledged.
} 


\section{Introduction}

The Foreign Agent Registration Act of 1938 (FARA) provides a legal channel for foreign governments and businesses to lobby the U.S. government. The main restriction is that such foreign "principals" cannot lobby government representatives directly, but must hire an "agent" based in the U.S. These agents may contact U.S. government representatives on behalf of the foreign agent. Through this FARA channel, lobbying by foreign governments and foreign businesses has become a large and thriving industry. The total amount expended by U.S. based agents on behalf of their foreign principals is of the same order of magnitude as the total amount of spending by all domestic political action committees (PACs).

Foreign lobbying is not necessarily the purview of rich countries. Since expanding trade with the U.S. is among the chief motives for foreign lobbying, a variety of rich and poor countries participate in lobbying activities through FARA channels. For example, in 1999 more than 1,000 principals from 160 countries sought to engage the attention of U.S. policymakers through the FARA channels (Department of Justice, FARA site, 2003). FARA agents reported that nearly $\$ 600$ million was spent by the foreign principals, approximately the same magnitude as spending by domestic political action committees.

How do FARA agents lobby on the principals' behalf? An important restriction is that FARA agents are not permitted to contribute to political election campaigns on behalf of their foreign agents. ${ }^{2}$ Thus, a significant part of the expenditures that FARA agents make on their clients' behalf are on informational activities. Such activities may be conducted through the media, but also by disseminating informational materials to legislators, government agencies, public officials, as well as civic and educational groups who, in turn, can influence policymakers. ${ }^{3}$ We adopt the view that FARA lobbying is primarily informational lobbying of policymakers (although as fn. 2 indicates, clients' monies can indirectly be channeled into campaign contributions).

\footnotetext{
${ }^{2}$ Nevertheless, being U.S. citizens, they and their relatives can, and do, make campaign contributions. It is not well known if, while making campaign contributions, they also verbally make known their preferred policy position (which is motivated by their foreign client) to the recipient.

${ }^{3}$ The sixteen-question registration form CRM-153 (formerly OBD-63) that FARA agents are required to fill out every 6 months inquires into the details of informational lobbying activities.
} 
In this paper we focus on lobbying by a group of Caribbean countries that seek to promote trade with the U.S. The objective of the paper is two-fold. The first objective is to empirically investigate whether lobbying on tourism related issues by Caribbean principals via their U.S. agents accomplishes the purpose of expanding tourism trade with the U.S. The second objective is to empirically explore an economic mechanism by which foreign lobbying might expand tourism. Specifically, we investigate whether foreign lobbying affects the elasticity of tourism demand in the Caribbean countries. Neither of these goals we have set out has a precedent in the literature. There are policy implications as well from this study, since in these countries most of their export earnings are tourism-related.

In the economics literature, the only other formal empirical studies of foreign lobbying of which we are aware are Gawande, Krishna, and Robbins (2006), which studies the impact of foreign lobbying on U.S. protectionism, and Kee, Olarreaga and Silva (2004) which studies whether South American lobbies succeeded in lowering U.S. tariff preferences against those countries. Both studies indicate that foreign lobbying has beneficial effects for the countries that engage in such lobbying. Despite the emergence of these studies, foreign lobbying remains understudied, and is absent in the context of tourism promotion.

The focus on the promotion of tourism in relatively less developed countries has deeper motivation. Copeland (1991) shows that if prices of non-tradable goods increase due to an expansion of tourism, then it raises welfare. Thus, with appropriate redistribution of the gains, the rising tide of tourism has the potential to lift all boats. Specifically, it is possible for tourism to lift low-income persons out of poverty. Common, though not empirically established, is the belief that in small low-to-middle income countries tourism can also spur growth. Copeland shows that when real income increases due to an expansion of tourism, it reinforces the increase in the price of non-tradable goods (provided they are normal goods, which we assume), thereby improving welfare further. ${ }^{4}$ Less formal models have also drawn the connection between

\footnotetext{
${ }^{4}$ If hotels and resorts, whose services are consumed intensively by tourists, are owned largely by foreigners, this may not hold. If the income from these assets is repatriated to foreigners then Copeland (1991, eq. (8)) shows that the increase in the prices of non-tradable goods is smaller and so are the welfare gains from expanding tourism. If income repatriation is sufficiently large it is possible for an increase in tourism to lower welfare. Another qualification to the conclusion that increasing tourism is welfare expanding through its effect on the prices of non-tradable goods is if factors are mobile. By making the supply of services more elastic, factor movements (induced by an increase in tourism) dampen the rise in nontradables prices.
} 
tourism and development (see e.g. Sinclair 1998). Thus, promoting tourism through lobbying appears to be a worthwhile enterprise, if such lobbying is indeed effective.

Engaged heavily in such an enterprise are Caribbean governments and lobbies in those countries connected with the tourism industry. Jobst's (2002) data summaries of foreign lobbying (Jobst, 2002, Table 4) indicate that Latin American and Caribbean countries accounted for over 25 percent of total foreign lobbying in the U.S. over the 1990-2000 decade. Are foreign lobbies successful in achieving their aim of increasing tourism? What is the quantitative impact of lobbying on tourism? Via what economic mechanism might lobbying lead to increased tourism? These are the questions addressed in this paper.

If the results show lobbying to be effective, they have a practical and straightforward policy implication for foreign countries. Countries endowed with natural amenities can, through legal lobbying channels, increase tourism by putting out information about those amenities as well as earning endorsements from the client country's government. Further, if lobbying also makes tourism less price sensitive, then lobbying has the potential to enable tourism to become an engine of economic development.

The paper proceeds as follows. Section 2 describes foreign lobbying institutions in the U.S. Section 3 describes the econometric model and data used to examine an exploratory econometric model of the impact of lobbying on tourism. Section 4 discusses these results. In Section 5 we use Copeland's theory to uncover another channel of influence, namely the potential for lobbying to make a destination less price-elastic. The exploratory model is extended to test this new hypothesis. Section 6 concludes. 


\section{Foreign Lobbying in the U.S.: Significance of Foreign Tourism Lobbies}

A ban on direct contributions by foreign nationals to politicians was first enacted in 1966 as part of the amendments to a 1938 internal security statute known as the Foreign Agents Registration Act (FARA). The goal of the FARA was to minimize foreign intervention in U.S. elections by establishing a series of limitations on foreign nationals. ${ }^{5}$ However, foreign nationals could hire U.S.-based foreign agents (primarily law firms) to gain access to U.S. policymakers and influential persons associated with policymakers. It was a requirement under FARA for all such activities to be reported.

Foreign lobbying encompasses a wide range of activities, including lobbying those connected with the U.S. government, lobbying the media, and incurring expenditures on promoting trade through advertising (see e.g. Husted, 1991). Jobst (2002, Table 7) indicates that 85 percent of FARA expenditures by Latin American lobbies during the 1990s was spent on export promotion. We presume that money is expended primarily to informationally lobby U.S. policymakers in order to promote exports. Informational lobbying seeks to inform rationally ignorant politicians about the benefits of changing their policy position, to a policy position closer to that of the lobbyist (see e.g. Grossman and Helpman 2002). ${ }^{6}$

In this paper we consider the case of lobbying of policymakers or individuals with access to policymakers in the U.S. by Caribbean principals (via their agents in the U.S.). Many Caribbean principals are in fact government agencies, primarily tourism boards, entrusted with

\footnotetext{
${ }^{5}$ In 1974, this ban was incorporated into the Federal Election Campaign Act (FECA). FECA prohibits any foreign national from contributing, donating or spending funds in connection with any federal, state, or local election in the United States, either directly or indirectly.

${ }^{6}$ A simple idea that has been examined in other trade contexts (Rauch and Trindade 2002, 2003) is that trade occurs only if traders in different countries want to trade. The process by which buyers are matched with sellers is not costless. Rauch and Trindade (2002) investigate how ethnic networks are able to overcome frictions due to language barriers, differing customs, and unfamiliar institutions and promote trade. They conclude: "Our results point to .... inadequate information regarding trading opportunities... Regarding information, it is common for governments to sponsor trade missions and to run international trade promotion organizations...... Yet ... such efforts complement rather than substitute for the services of private intermediaries because the latter provide greater depth of information." We imagine that in our case lobbying by Caribbean principals is used to overcome informational barriers in order to "match" their natural amenities with potential tourists. Just as ethnic networks do, lobbying arises as a mechanism to promote tourism via the use of private intermediaries (U.S. agents) that are specialized in their connections with groups of policymakers.
} 
ensuring a steady flow of tourists every season. We note that in the data we consider, the expenditures are not spent on media or advertising but on their agents who, in turn, informationally lobby policymakers by informing them on issues that concern them. Since a welfare minded government is receptive to ideas that concern the safety of its citizens, informational lobbying may provide new information by the foreign principal about how they may have improved the security of their island, the resources they have invested in controlling the spread of a disease to their island, the steps they have taken to ensure the safety of U.S. citizens in the event of a natural calamity by building weather-proof shelter or an effective evacuation plan, and the investment they may have undertaken to make their hotels and buildings more able to withstand hurricanes.

Since tourists look up the State Department's website for information on these and other issues before deciding upon their vacation destination, negative reporting on those accounts can decimate tourism. Lobbying may be directed at providing information to counter or soften any negative information that the State department may otherwise place on their website, ${ }^{7}$ or provide positive information on how the government of a destination has undertaken activities to ensure the safety of tourists. This is the primary mechanism by which lobbying may influence tourism. The purpose of this paper is to investigate whether the data shows that this type of lobbying in fact achieves its purpose.

The data set used in the estimation of our empirical model was assembled using reports that FARA requires the U.S. Attorney General to make available to Congress. The report collects information about foreign agents operating within the United States. A foreign agent, in the view of the U.S. Department of Justice, is somebody who (a) engages in political activities or acts in a public relations capacity for a foreign principal, (b) solicits or dispenses anything of value within the United States for a foreign principal, or (c) who represents the interests of a

\footnotetext{
${ }^{7}$ For example, despite an occasional incident of terrorist bombings in Delhi, the capital city of India, there has been no overtly negative assessment of the city as a tourist destination on the State Department's website. As another example, the government of Kazakhstan very effectively employed Washington lobbyists in 1999 to improve the country's image in the press and the U.S. Congress (See Harper's Magazine "Plenty of Loopholes in New Lobbying Regulations" 2007 http://www.harpers.org/sb-plenty-of-loopholes-1168542976.html) Recently, the government is reported to have launched another lobbying effort to provide information counteracting the negative image of the country portrayed by the character Borat in the popular movie "Cultural Learnings of America for Make Benefit Glorious Nation of Kazakhstan (2006)."
} 
foreign principal before any agency or official of the U.S. government. ${ }^{8}$ Each entry in the FARA annual reports contains (i) the name and address of the foreign agent, (ii) the name of the foreign principal (usually a private firm, an industry association, or a government agency), (iii) the purpose of the agency, including any U.S. government entities contacted, and (iv) amount of money paid to the agencies for their services. ${ }^{9}$ The results presented in this paper use data taken from the reports that covered calendar years 1990-99.

\section{Econometric Model and Data}

\subsection{Econometric Model}

We use a panel data model to study the impact of foreign lobbying on tourism:

$$
\text { LTOURISTS }_{i t}=\beta \mathrm{LLOB}_{i t-1}+\alpha_{1} \mathrm{LPCGDP}_{i t}+\alpha_{2} \mathrm{LRER}_{i t}+c_{i}+u_{i t}
$$

In (1), $i$ indexes the 13 destination countries in the Caribbean, and $t$ indexes years 1991-2000. LTOURISTS $_{i t}$ is the $\log$ of the number of U.S. tourist arrivals in country $i$ during year $t$ and $\mathrm{LLOB}_{i t-1}$ is the $\log$ of tourism-related foreign lobbying spending during year $t-1$ by foreign principals in country $i$. The coefficient of interest $\beta$ is the elasticity of U.S. tourist arrivals with respect to foreign lobbying spending by principals in country $i$.

We wish to exploit within-country variation in lobbying and tourism and therefore choose a fixed-effects model specification. The country fixed effects are denoted $c_{i}$. They are intended to pick up unobserved effects including, among other things, government policy towards tourism, multiple measures of natural "sun, sea and sand" amenities (for example, opportunities for scuba diving), and attractiveness of the island's unique culture. In fixed-effects models, the unobserved effects may be correlated with other regressors without inducing bias.

\footnotetext{
${ }^{8}$ From the FARA document at http://www.usdoj.gov/criminal/fara/q A.htm.

${ }^{9}$ Often the exact dollar amount of spending by the FARA agent is left blank. For example, of the 1500 individual FARA entries in 1990, about 1000 reported a dollar amount of transactions. We proceed by using the reported dollar amounts, and presume that the unreported amounts are either negligible or are randomly missing.
} 
We include two additional variables. The log of real per capita GDP (LPCGDP) is motivated by gravity considerations (see below). This variable is also an adequate proxy for amenities that are correlated with the island's economic development, for example, security, transportation, and infrastructure, which are hard to measure directly. The log of the real exchange rate (LRER) captures the price sensitivity of the tourism demand. Considering the proximity of one destination to another, variation in a destination's price should play a role in determining variation in the amount of tourist arrivals at that destination. Below (see Section 5) this variable is also interacted with LLOB in order to capture the effect of foreign lobbying on the tourism demand elasticity. Finally $u_{i t}$ encompasses unexplained tourism shocks. We presume these shocks to have constant variance and to be cross-sectionally and serially uncorrelated.

An alternative model to (1) is the gravity model (Leamer and Stern (1970), Anderson (1979) and Bergstrand (1985)). The main idea behind the gravity equation is that bilateral distances and incomes are the primary determinants of trade. That the gravity equation can be derived from different models in fact makes it appealing for studying tourism. Surprisingly, neither the empirical literature in economic journals nor in hospitality-and-tourism-industry journals contains application of the gravity equation. For example, the survey of empirical models of tourism in Lim (1997) and Sinclair (1998) has no mention of the gravity model. In the presence of fixed effects, time-invariant variables that are considered important to gravity models (e.g. dummy for common language, COMLANG; the log of land areas, LAREA; and the log of distance, LDIST) become redundant. Therefore, in order to investigate the gravity model, we also estimate a random effects model with gravity variables. The log of exports of goods (LRX) is also included as a measure of the importance of traditional trade in the country's economy. We find the gravity model to not only be empirically well-suited to study the number of tourist visits, but it also affirms the fixed effects results. ${ }^{10}$

\subsection{Data}

The Caribbean Tourism Organization tabulates time series on tourist flows by destination and origin from the statistical and tourism offices of its member states in the annual Caribbean

\footnotetext{
${ }^{10}$ Gravity model variables (described below) were taken from the data set at the site http://faculty.haas.berkeley.edu/arose/RecRes.htm\#Software made available by Andrew Rose, and used in Rose and Spiegel (2003).
} 
Tourism Statistical Report. The CTO has adopted the international definition of "tourist" advocated by the World Tourism Organization of "Any person visiting a country other than that in which they normally reside, for not more than one year, and whose purpose of visit is leisure, business (including meetings, study and research) health treatments, religious pilgrimages, and aircraft and ship crew stayover." Most statistics are obtained by analysis of embarkation / disembarkation cards completed for the national immigration authorities. In cases where a tourist card is not required because travel is consider domestic (e.g. U.S. to Puerto Rico of U.S. Virgin Islands), greater reliance is put on the analysis of hotel registrations. We focus on stayover tourists which is the larger and more lucrative market.

Data on lobbying in tourism by foreign principals residing in the Caribbean destinations for the period 1990-99 was compiled from FARA reports for those years. In each year there were about 1,300 entries containing data on the calendar year of the activity, the country of the principal, the name of the principal, and the amount of money the agent and principal transacted. On the basis of the description of the representation activity by the U.S. agent in the FARA report, each entry was assigned a primary 3-digit SIC industry. Over 25 percent of the FARA entries were in the tourism sector (SIC 961). Those entries from the Caribbean destinations are used in this study. ${ }^{11}$ They are aggregated up to the country level for each year.

In the FARA reports, dollar figures for the three years 1992-94 are completely missing. However, foreign principals who lobbied are quite completely identified. In order to obtain a complete sample with no discontinuities, we imputed lobbying expenditures for each identified principal for the missing years, based on how much they spend on lobbying in other years. The imputed value, in 1992 for example, for a specific principal is simply the predicted lobbying spending from a trend equation for that principal for 1992. In general the trend equations fit the data adequately. These imputed values are then aggregated up to the country level.

We restrict the sample to countries that participated in foreign lobbying at least once during this period, because we want to exploit the within-country variation in lobbying across time, and only if countries participated would we expect to see their impact on tourism. If in any year one of these countries did not participate in U.S. lobbying, lobbying spending for that

\footnotetext{
${ }^{11}$ Only data on lobbying devoted to tourism (SIC 961) are used in this study. Data on lobbying devoted to advertising (SIC 731) and to media and media relations (SIC 874) are excluded from the study. Thus, the analysis is focused exclusively on lobbying for tourism.
} 
country was set to $\$ 1$, so that log of lobbying (LLOB) equaled zero. That is, there was no informational lobbying by those Caribbean principals.

Per capita GDP is taken from the CTO. The real exchange rate (RER) is measured as the nominal exchange rate (island's currency per dollar) times the ratio of the U.S. CPI (1995 base) to the island's price level (1995 base). The RER is standardized to a value 1 in the 1995 . The RER is taken from World Development Indicators (2003) and CTO.

Complete data on the lobbying and tourism variables were available for one or more years during the ten -year period for these thirteen countries: Aruba, Barbados, Netherlands Antilles (Bonaire and Curaçao), Belize, Bermuda, Cayman Is., Dominica, Dominican Rep., Grenada, Jamaica, Montserrat, St. Lucia, Trinidad and Tobago. Our sample is thus a balanced panel consisting of 130 observations.

Over the 1990-2000 period the 13 destinations accounted for 38 percent of the total tourist arrivals in the Caribbean, and 32 percent of the U.S.-Caribbean tourism (U.S. tourists account for more than a half of total arrivals in the Caribbean). These destinations accounted for about 70 percent of the total reported foreign lobbying spent by all the Caribbean destinations (about $\$ 306 \mathrm{mn}$.).

\section{Results}

Our empirical strategy is to first estimate a baseline model with and without fixed-effects in order to observe whether, all else held constant, foreign lobbying is positively associated with tourism. Next, we take care of the endogeneity of lobbying spending. If decisions about the amount of foreign lobbying expenditures are based on expectations about how they might impact on tourism, then it is likely that the variable LLOB is endogenous. Thus, we estimate the fixedeffects models using instruments. Finally, we present estimates from the gravity model using a random effects specification.

Table 1 presents OLS and fixed effects (FE) estimation of the baseline model in equation (1). The OLS model estimate the elasticity of lobbying to be 0.12 , implying that a 10 percent increase in foreign lobbying expenditure increase tourism arrivals by 1.2 percent. Including fixed-effects indicates that the OLS model overestimates the lobbying elasticity. The FE model yields a smaller estimate of 0.032, implying that a 10 percent increase in foreign lobbying expenditure increase tourism arrivals by 0.32 percent. Although small, the elasticity is estimated 
with precision. The elasticity of tourism with respect to the island's income is substantial in the FE model - a 10 percent increase in per capita income increase tourism arrivals by 14.57 percent.

It is likely that decisions about the amount of foreign lobbying expenditures are based on expectations about how they might impact tourism. Then, the variable LLOB is endogenous. In order to correct for possible endogeneity of LLOB, a two-stage procedure is used in which LLOB is predicted using an exogenous instrument in addition to the regressors in (1) in the first stage, and the predicted values are used in place of LLOB in the second stage. The instrument we use, denoted ASSET, is the external asset positions of reporting banks on the islands. Data on ASSET are from Bank of International Settlements. Its use is motivated by the fundamental instrumental variables (IV) idea of finding variables that are related with the lobbying variable LLOB but not the error term in the baseline regression.

Foreign lobbying is partly designed to attract U.S. institutions and individuals to use the services of Caribbean financial institutions that are less stringently regulated than their developed country counterparts. Since such lobbying spending is likely to be correlated with the size of external assets, the financial variable ASSET is correlated with LLOB. However, foreign lobbying directed at increasing participation by U.S. institutions and individuals in their financial sectors, for example offshore banking, is unrelated with the error term in the tourism regressions since shocks to the number of tourist arrivals (for example, due to inclement weather during a particular season) have little impact on financial sector participation. Further, there is no evidence in the literature of any significant participation of tourists in the Caribbean financial sector. To reduce any remaining doubt about its exogeneity, the two-period lagged value of ASSET is used to instrument LLOB.

The IV estimates reported in Table 2 indicate that correcting for the endogeneity of LLOB using the financial variable greatly increases the size of the quantitative association of foreign lobbying and U.S. tourism (Table A1 in the Appendix reports the first stage regressions). The elasticity of lobbying spending on tourism is estimated to be 0.296 , indicating that doubling lobbying spending increases the number of tourist arrivals from the U.S. by approximately 15 percent. Doubling, or even quadrupling, lobbying spending is easily accomplished by countries that have a small or negligible political presence in the U.S.

The order of magnitude increase in the lobbying coefficient deserves further explanation. In (1) LLOB is negatively correlated with the error term (contemporaneous shocks) because 
destinations that are traditionally popular for American tourists are likely to already have a wellorganized lobbying sector. When they experience or predict a negative shock these islands step up their lobbying, and during years in which they expect no shocks they step it down. Thus, the FE estimates of Table 1 are downward biased. Instrumenting LLOB removes this bias and increases the magnitude of the lobbying coefficient. The size of this increase is surprising.

Thus, the potential for foreign lobbying to work to increase tourism and, in turn, spur development is substantial. For countries such as the Cayman Islands that already have a large inflow of U.S. tourists, this implies a substantial increase in the number of tourists since the tourist base on which this percentage increase applies is already large. For smaller countries that do not lobby up to their potential, this estimate could potentially imply a substantial increase in tourism via a large, say, five-fold increase in lobbying spending.

\section{Gravity model}

Table 3 presents random effects (RE) estimates for two models: the baseline model with the three original regressors, and the gravity models with additional time-invariant regressors. The reported Hausman test statistics (collectively for all coefficients and individually for LLOB) indicate that in the baseline model we cannot reject the null hypothesis that estimates from the RE model are consistent. The RE estimates are statistically close to their FE counterparts.

The inclusion of the gravity variables induces an increase in the coefficient estimate of LLOB of about one standard error. Also notable is the positive and statistically significant coefficient on the log of the real exchange rate (LRER), indicating a price effect at work. The coefficients on the gravity variables are of interest, independently of the lobbying issue, in order to assess whether the use of the gravity model is appropriate. Our estimates suggest that it is. One of the central gravity variables (LDIST) indicates that tourism declines with distance: a 100 percent increase in distance decreases tourism by about the same magnitude. This is in line with the travel cost intuition behind the use of this variable. Also connectedly with the idea of the gravity model, the greater the destination country's land area (LAREA), the greater the number 
of tourists it receives. The amount of exports (LRX), and whether its primary language is English (COMLANG) appears to matter little to tourism ${ }^{12}$.

Table 4 shows the corresponding IV correction for endogeneity using Baltagi's (1981) error-component two-stage least squares (EC2SLS) method (Table A2 in the Appendix reports the first stage regressions). ${ }^{13}$ Just as in the fixed effects model, the gravity model without instrumenting for LLOB has a much smaller lobbying elasticity coefficient than after instrumenting for LLOB. The gravity model IV estimates in Table 4 show a similar estimate (0.331) with smaller standard errors. Overall they affirm the results obtained in Tables 1 and 2.

Having demonstrated evidence about the possibly strong link between lobbying by Caribbean principals and U.S. tourist arrivals on Caribbean destinations from a reduced form gravity model, we investigate a structural explanation for why this may be so. The empirical evidence presented in the next section is a simple extension of the model estimated here to include variables that account for a hypothesized mechanism.

\section{A Structural Mechanism}

The models examined thus far were exploratory in nature. The empirical estimates from those models demonstrated economically significant and statistically precise estimates of the influence of lobbying by foreign principals on tourist flows to those destinations from the U.S. We now explore a structural model that (i) provides a firm theoretical basis for the exploratory models, and (ii) advances a more subtle hypothesis about price effects.

Formally, this mechanism is best understood using Copeland's model of tourism demand. Suppose tourist destinations produce three goods - manufacturing, agriculture, which are tradable, plus services, which is nontradable. Tourism demand for the three domestic goods is given by the 3 -component vector $D(p, a, \alpha) . \quad p$ is the price vector of the three goods, which compete for tourists' expenditures. Denote by $p_{n}$ the price of services. $a$ is a vector of exogenously given country characteristics which serves to make each tourist destination a

\footnotetext{
${ }^{12}$ Only Dominic Republic and the Netherlands Antilles do not have English as their official language. However, tourist resorts' workers have fluent English.
} 
differentiated product. Since tourists consume goods and services jointly with the unique natural amenities of a destination country, even small countries (e.g. the Caribbean islands) face inelastic demand curves and need not be price takers. $\alpha$ is a shift parameter that shifts out each component of the tourist demand vector: $\partial D_{i} / \partial \alpha>0, i=$ agriculture, manufacturing, services.

Theoretically, foreign lobbying might serve two purposes. It might work as the shift parameter $\alpha$, which promotes tourism and thus increases tourism. Foreign lobbying (e.g. by Caribbean principals) might also "create" domestic amenities $a$ via lobbying of the government who, in turn, provide new information to potential tourists about existing and new amenities, that it is a destination that is "safe and free of diseases", that it is "easier for foreigners due to a common language", or that the destination "cares about security". Such information serves two purposes: it makes demand less elastic and shifts tourism demand.

We hypothesize that foreign lobbying affects tourism through those two channels. Lobbying the U.S. government is used to create a differentiated product, one that is more priceinelastic. Second, lobbying is used to shift out the demand curve for tourism. By obtaining an implicit or explicit endorsement by the U.S. government, lobbying can spur tourism. ${ }^{14}$ With a fixed or inelastic supply of services in the short-run, any increase in tourism has the salubrious effect of increasing nontradables prices far more than if the demand were elastic. As shown in Copeland (1991), the greater the increase in nontradables prices, the more welfare improving the increase in tourism. This motivates the following econometric model to estimate whether foreign lobbying (i) acts as a shift parameter, and (ii) decreases the price elasticity of tourism demand:

\section{LTOURISTS $_{i t}=$}

$$
\beta_{1} \mathrm{LLOB}_{i t}+\beta_{2} \mathrm{LRER}_{i t}+\beta_{3}\left(\mathrm{LRER}_{i t} \times \mathrm{LLOB}_{i t}\right)+\beta_{4} \mathrm{LPCGDP}_{i t}+c_{i}+\varepsilon_{i t}
$$

\footnotetext{
${ }^{13}$ For the random effects model estimates to be consistent we must make the assumption that regardless of the time period, the observed regressors in (1) are strictly exogenous conditional on the unobserved effects $C_{i}$.

${ }^{14}$ In the context here, the extant Caribbean Basin Initiative can be modified to give preferential access (say, to U.S. tourists or tourism-related foreign direct investment by U.S. businesses) more easily than if there were no such agreement in place.
} 
The price elasticity of demand for tourism $\partial$ LTOURISTS/OLRER $=\beta_{2}+\beta_{3}$ LLOB. This elasticity is positive. As U.S. prices rise relative to Caribbean prices, all else constant, the demand for tourism rises; or if the nominal exchange rate increases and the dollar appreciates, all else held constant, the demand for tourism rises. The influence of foreign lobbying by Caribbean principals on the price elasticity of demand by U.S. tourists is captured by the coefficient $\beta_{3}$. If foreign lobbying makes U.S. tourism less elastic then $\beta_{3}<0$. This is the hypothesis we test.

We estimate model (2) using fixed effects and an extended gravity specification with random effects. In both cases, we account for the endogeneity of LLOB by instrumenting it with ASSET. The results are presented in Table 5. They continue to affirm the hypothesis that foreign lobbying acts as the "shift parameter" to increase tourism. That is, $\partial \mathrm{LTOURISTS} / \partial \mathrm{LLOB}>0$. The new result is the negative and statistically coefficient on the interaction term LRER $\times$ LLOB, which affirms the hypothesis that lobbying decreases the price elasticity of tourism demand. The estimates on the interaction term are economically significant in both models. In the fixed effects model, the price elasticity of Caribbean tourism demand by U.S. tourists (OLTOURISTS/OLRER) decreases by 21.3 percent with a doubling of lobbying spending. ${ }^{15}$ The gravity model estimated using random effects indicates a similar decrease (20.3 percent). These magnitudes are striking and lend credence to the mechanism described above, namely that foreign lobbying provides new information about existing amenities at a tourist destination, thus making demand less elastic. Destinations that are politically represented by lobbyists are therefore able to successfully differentiate their destinations from others. The end result is that, like advertising, lobbying creates differentiated goods for which demand is much less elastic than in more competitive markets. The advantage here is that lobbying costs much less than advertising.

\section{Conclusion}

The question of whether lobbying by foreigners can effectively promote their business interests is the broad issue with which this paper is concerned. The Foreign Agent Registration Act allows foreign principals to lobby inside the United States via U.S.-based agents. Lobbying can target U.S. policymakers directly, when U.S.-based agents directly contact them to provide

\footnotetext{
${ }^{15}$ This is evaluated at the mean of LLOB (equal to 6.1).
} 
information, or indirectly through contact with their aides. Most foreign lobbying appears to be informational, since foreigners are prohibited from contributing to election campaigns. The amounts expended by foreign principals are still substantial. Total foreign lobbying spending in the U.S. rivals political spending by domestic PACs.

This paper empirically explores the specific subject of tourism-related foreign lobbying by Caribbean principals. These principals include Caribbean governments and individuals in the private sector. We match U.S. tourist arrivals in Caribbean destinations annually between 19912000 with the total amount of lobbying spending by Caribbean principals. Estimates from fixed effects models and random effects gravity model indicate a strong positive association between foreign lobbying spending and the number of U.S. tourists. The relationship is quantitatively significant as well. A number of sensitivity analyses affirm this association. Further, lobbying appears to decrease the price elasticity of tourism demand, that is, destinations that lobby are able to differentiate their product. This finding suggests that foreign lobbying may be strategically used to increase tourism.

The answer to the question posed in the title of the paper is thus, in the affirmative. The implications for developing economies are obvious. There exists a legal channel for lobbying in the U.S. that might be used by governments and individuals alike to promote trade and tourism with the U.S. Rauch and Trindade (2002) emphasize the role that informational barriers play in restricting trade, and how networks overcome those barriers. Lobbying by foreign principals may also be viewed as a mechanism of overcoming informational barriers. While advertising may accomplish the same task, it is expensive to do. Further, advertising is far less credible on destination characteristics about which U.S. tourists really care - safety from diseases, security, protection against natural calamities - than an assenting nod from the U.S. government in the form of such information posted on the State Department website.

Our results are among the first in the literature and therefore deserve scrutiny. For example, we have used the general price level in computing the real exchange rate to infer whether lobbying makes tourism demand inelastic. An improvement would be to use more hardto-find sector-specific price data for this purpose. It is also relevant to question whether lobbying participation by all islands would have the same impact as reported in this paper, or whether lobbying competition would result in rent transfers to the government being lobbied. 


\section{References}

Anderson, James E., (1979) “A Theoretical Foundation for the Gravity Equation,” American Economic Review 69, 106-16.

Bank of International Settlements site: http://www.bis.org/statistics/bankstats.htm.

Bergstrand, Jeffrey H. 1985. "The gravity equation in international trade: Some microeconomic foundations and empirical evidence." Review of Economics and Statistics 67, 474-481.

Caribbean Tourism Organization. 1990-2002. Caribbean Tourism Statistical Report, Barbados. World Development Indicators (CD-ROM) 2003. Washington DC: World Bank.

Copeland, Brian, R. 1991. "Tourism, welfare, and de-industrialization in a small open economy," Economica 58, 515-529.

Deardorff, Alan V. 1998. "Determinants of bilateral trade: Does gravity work in a neoclassical world?" In J. A. Frankel (ed.) The Regionalization of the World Economy. Chicago, IL: University of Chicago Press.

Department of Justice. FARA site: http://www.usdoj.gov/criminal/fara.

Gawande, Kishore, Pravin Krishna, and Michael Robbins. 2006. "Foreign lobbying and U.S. trade policy," Review of Economics and Statistics 88, 563-571.

Grossman, Gene and Elhanan Helpman. 2002. Special Interest Politics. Cambridge, MA: MIT Press.

Harper's Magazine. 2007. "Plenty of Loopholes in New Lobbying Regulations". Site: http://www.harpers.org/sb-plenty-of-loopholes-1168542976.html

Husted, Steven. 1991. "Foreign lobbying: A theoretical analysis." The Eastern Economic Journal 17, 89-99.

Jobst, Andreas. 2002. Foreign lobbying in the U.S. - A Latin American perspective. Manuscript. 
Kee, Hiau Looi, Marcelo Olarreaga and Peri Silva. 2004. "Market access for sale: Latin America's lobbying for U.S. tariff preferences", World Bank Policy Research Working Paper Series \#3198.

Leamer, Edward and Robert Stern. 1970. Quantitative International Economics. Boston: Allyn and Bacon.

Lim, Christine. 1997. "Review of international tourism demand models." Annals of Tourism Research 24, 835-849.

James E. Rauch and Vitor Trindade, 2002. "Ethnic Chinese Networks in International Trade," Review of Economics and Statistics 84, 116-130.

James E. Rauch and Vitor Trindade, 2003. "Information, International Substitutability, and Globalization," American Economic Review 93, 775-791.

Rose, Andrew K. and Mark M. Spiegel. 2002. "A gravity model of sovereign lending: Trade, default and credit.” NBER Working paper \#9285.

Sinclair, M. Thea. 1998. "Tourism and Economic Development: A Survey" Journal of Development Studies 34, 1-51.

Suss, Esther C., Oral H. Williams, and Chandima Mendis. 2002. "Caribbean offshore financial centers: Past, present, and possibilities for the future." IMF Working Paper WP/02/88. 
Table 1 - Baseline model

\begin{tabular}{lc|c|}
\hline \hline Dep.var.: LTOUR & OLS & FE \\
\hline LLOB & $0.118^{* * *}$ & $0.032^{* *}$ \\
& $(0.025)$ & $(0.013)$ \\
LRER & -1.132 & 0.449 \\
& $(1.335)$ & $(0.328)$ \\
LPCGDP & 0.225 & $1.457 * *$ \\
& $(0.333)$ & $(0.635)$ \\
Obs. & & \\
Groups & 130 & 130 \\
$\mathrm{R}^{2}$ & & 13 \\
& 0.189 & 0.971 \\
\hline \hline
\end{tabular}

Notes:

1. Standard errors in parenthesis. Significance level: * $10 \%$, $* * 5 \%, * * * 1 \%$.

2. OLS: ordinary least squares. FE: fixed effects. 
Table 2 - Instrumental variables estimation

\begin{tabular}{l|c}
\hline \hline Dep.var.: LTOUR & FE IV \\
\hline LLOB & $0.296^{*}$ \\
& $(0.170)$ \\
LRER & 1.014 \\
& $(0.719)$ \\
LPCGDP & $1.551^{* *}$ \\
& $(1.220)$ \\
& 117 \\
Obs. & 13 \\
Groups & 0.9106 \\
$\mathrm{R}^{2}$ & 3.29 \\
IV F-test & \\
\hline \hline
\end{tabular}

Notes:

1. See Notes to Table 1.

2. FE IV: fixed effects model where LLOB is instrumented by ASSET (see Table A1 for the first stage regressions).

3. IV F-test reports the first-stage F-statistic for the instrument. 
Table 3 - Gravity Model

\begin{tabular}{l|c|c}
\hline \hline Dep.var.: LTOUR & $\mathrm{RE}$ & $\mathrm{RE}$ \\
\hline LLOB & $0.034^{* * *}$ & $0.051^{* * *}$ \\
LRER & $(0.013)$ & $(0.013)$ \\
& 0.370 & $0.697^{* *}$ \\
LPCGDP & $(0.314)$ & $(0.326)$ \\
& $1.208^{* *}$ & $2.413^{* * *}$ \\
LRX & $(0.528)$ & $(0.470)$ \\
& & -0.023 \\
LDIST & & $(0.045)$ \\
& & $-1.248^{*}$ \\
LAREA & & $(0.693)$ \\
& & $0.724 * * *$ \\
COMLANG & & $(0.107)$ \\
& & -0.178 \\
Obs. & & $(0.365)$ \\
Groups & & 130 \\
R & & 13 \\
Hausman test & & \\
(p-value) & & \\
All coefficients & $(0.508)$ & \\
& $(0.167)$ & \\
\hline \hline LLOB & & \\
\hline
\end{tabular}

Notes:

1. See Notes to Table 1.

2. RE: random effects. 
Table 4 - Gravity Model, IV estimates

\begin{tabular}{l|c|c}
\hline \hline Dep.var.: LTOUR & RE IV & RE IV \\
\hline LLOB & $0.340^{* * *}$ & $0.331^{* *}$ \\
& $(0.184)$ & $(0.164)$ \\
LRER & 0.882 & $1.155^{*}$ \\
LPCGDP & $(0.715)$ & $(0.667)$ \\
& 0.857 & $1.837^{* *}$ \\
LRX & $(1.086)$ & $(0.833)$ \\
& & 0.025 \\
LDIST & & $(0.080)$ \\
& & -0.238 \\
LAREA & & $(1.091)$ \\
& & $0.872^{* * *}$ \\
COMLANG & & $(0.183)$ \\
& & -1.358 \\
Obs. & & $(0.897)$ \\
Groups & 117 & 117 \\
R & & 13 \\
IV F-test & & 0.7527 \\
(p-value) & 0.1763 & 3.86 \\
& 3.14 & $(0.050)$ \\
\hline \hline
\end{tabular}

Notes:

1. See Notes to Table 1.

2. RE IV: random effects model using Baltagi's (1981) EC2SLS method where LLOB is instrumented by ASSET (see Table A2 for the first stage regressions). 
Table 5 - Structural model

\begin{tabular}{l|c|c}
\hline \hline Dep.var.: LTOUR & FE IV & RE IV \\
\hline LLOB & $0.261^{* * *}$ & $0.225^{* * *}$ \\
LRER & $(0.087)$ & $(0.038)$ \\
& $3.291^{* * *}$ & $3.178^{* * *}$ \\
LRER*LLOB & $(0.773)$ & $(0.773)$ \\
& $-0.213 * * *$ & $-0.203^{* * *}$ \\
LPCGDP & $(0.064)$ & $(0.064)$ \\
& $1.528^{* *}$ & $1.780^{* * *}$ \\
LRX & $(0.624)$ & $(0.453)$ \\
& & -0.026 \\
LDIST & & $(0.041)$ \\
& & -0.789 \\
LAREA & & $(0.731)$ \\
COMLANG & & $0.817 * * *$ \\
& & $(0.110)$ \\
Obs. & & $(0.411)$ \\
Groups & & $1.004 * *$ \\
IV F-test & & 117 \\
(p-value) & & 13 \\
\hline \hline
\end{tabular}

Notes:

1. See Notes to Table 2 and 4.

2. The predicted value of LLOB is used to construct LRER*LLOB in the second stage. 


\section{Appendix}

Table A1- First stage regression for Tables 2 and 4

\begin{tabular}{l|l}
\hline \hline Dep.var.: LLOB & FE \\
\hline ASSET & $0.468^{*}$ \\
& $(0.258)$ \\
LRER & -2.758 \\
& $(2.117)$ \\
LPCGDP & -3.849 \\
& $(3.994)$ \\
Obs. & 117 \\
Groups & 13 \\
$\mathrm{R}^{2}$ & 0.9179 \\
IV F-test & 2.41 \\
(p-value) & $(0.1239)$ \\
\hline \hline
\end{tabular}

Notes:

1. Standard errors in parenthesis, except when indicated. Significance level: $* 10 \%, * * 5 \%, * * *$ $1 \%$.

2. FE: fixed effects. 
Table A2- First stage regressions for Tables 3 and 5

\begin{tabular}{l|c|c}
\hline \hline Dep.var.: LLOB & RE & RE \\
\hline ASSET & $0.425^{*}$ & $0.481^{* *}$ \\
LRER & $(0.239)$ & $(0.245)$ \\
LPCGDP & -1.663 & -2.584 \\
& $(1.972)$ & $(2.046)$ \\
LRX & 0.091 & -2.824 \\
& $(2.87)$ & $(3.525)$ \\
LDIST & & -0.184 \\
& & $(0.266)$ \\
LAREA & & -3.519 \\
& & $(6.464)$ \\
COMLANG & & -1.114 \\
& & $(0.930)$ \\
Obs. & & 3.941 \\
Groups & & $(3.433)$ \\
R & & 117 \\
Hausman test & 3 & 13 \\
(p-value) & 0.0993 & 0.3489 \\
$\quad$ All coefficients & $(0.529)$ & \\
IV F-test & $(0.684)$ & \\
(p-value) & 3.14 & 3.86 \\
\hline \hline
\end{tabular}

Notes:

1. Standard errors in parenthesis, except when indicated. Significance level: * $10 \%, * * 5 \%, * * *$ $1 \%$.

2. RE: random effects. 